\title{
Bacillus lehensis sp. nov., an alkalitolerant bacterium isolated from soil
}

\author{
A. Ghosh, ${ }^{1}$ M. Bhardwaj, ${ }^{2}$ T. Satyanarayana, ${ }^{2}$ M. Khurana, ${ }^{1}$ S. Mayilraj ${ }^{1}$ \\ and R. K. Jain ${ }^{1}$ \\ ${ }^{1}$ Microbial Type Culture Collection and Gene Bank (MTCC), Institute of Microbial Technology, \\ Sector-39A, Chandigarh 160036, India \\ ${ }^{2}$ Microbiology, University of Delhi, South Campus, Benito Juarez Road, New Delhi 110021 , \\ India
}

\begin{abstract}
A Gram-positive, endospore-forming, alkalitolerant bacterial strain, designated $\mathrm{MLB2}^{\top}$, was isolated from soil from Leh, India, and was subjected to a polyphasic taxonomic study. The strain exhibited phenotypic properties that included chemotaxonomic characteristics consistent with its classification in the genus Bacillus. Growth was observed at pH 7.0-11.0, but not at pH 6.0. The DNA G + C content was 41.4 mol\%. The highest level of 16S rRNA gene sequence similarity was with Bacillus oshimensis JCM $12663^{\top}$ (98.8\%). However, DNA-DNA hybridization experiments indicated low levels of genomic relatedness with the type strains of $B$. oshimensis (62\%), Bacillus patagoniensis (55\%), Bacillus clausii (51\%) and Bacillus gibsonii (34\%), the species with which strain MLB2 ${ }^{\top}$ formed a coherent cluster (based on the results of the phylogenetic analysis). On the basis of the phenotypic characteristics and genotypic distinctiveness of strain MLB2 ${ }^{\top}$, it should be classified within a novel species of Bacillus, for which the name Bacillus lehensis sp. nov. is proposed. The type strain is $\mathrm{MLB}^{\top}\left(=\mathrm{MTCC} 7633^{\top}=\mathrm{JCM}\right.$ $\left.13820^{\top}\right)$.
\end{abstract}

In recent years there has been increasing interest in alkaliphilic and alkalitolerant micro-organisms, attributable to their ability to grow under extreme conditions as well as to the use of their enzymes in biotechnological applications. Naturally occurring alkaline environments, which include soda lakes, deserts and arid soils, harbour a wide range of alkaliphilic and alkalitolerant micro-organisms (Ulukanli \& Diurak, 2002). The genus Bacillus currently includes 19 species characterized as alkaliphilic and alkalitolerant (http://www.bacterio.cict.fr/b/bacillus.html), and many of them have been studied with a view to finding industrial applications (Horikoshi, 1991; Nielsen et al., 1995; Yumoto et al., 1998). Alkaliphilic enzymes (such as alkaline cellulases and alkaline proteases) produced by Bacillus species are used in the detergent industries (Horikoshi, 1999). In this work, we describe an alkalitolerant, endospore-forming bacterium, designated $\mathrm{MLB}^{\mathrm{T}}$, isolated from pristine soil samples from Leh, India (at $3500 \mathrm{~m}$ above sea level and at temperatures ranging from -20 to $30^{\circ} \mathrm{C}$ ). Characterization of the protease produced by the strain indicated optimal activity at $\mathrm{pH} 10.0$.

\footnotetext{
The GenBank/EMBL/DDBJ accession number for the $16 \mathrm{~S}$ rRNA gene
} sequence of strain MLB2 $^{\top}$ is AY793550.

A table showing the fatty acid compositions of strain $M L B 2^{\top}$ and its close relatives is available as supplementary material in IJSEM Online.
Strain $\mathrm{MLB}^{\mathrm{T}}$ was isolated on tryptone soya agar (TSA, $\mathrm{pH} 7.3$; HiMedia) at $25^{\circ} \mathrm{C}$ by means of the dilution plating technique. Subculturing was performed on TSA at $25^{\circ} \mathrm{C}$ for $24 \mathrm{~h}$ and the bacterial isolate was maintained as glycerol stock at $-70{ }^{\circ} \mathrm{C}$. Reference strains used were Bacillus oshimensis JCM $12663^{\mathrm{T}}$ (=MTCC $7915^{\mathrm{T}}$ ), obtained from the Japan Collection of Microorganisms (Saitama, Japan), and Bacillus patagoniensis DSM $16117^{\mathrm{T}}$ (= MTCC $\left.7916^{\mathrm{T}}\right)$, Bacillus clausii DSM $8716^{\mathrm{T}}$ (=MTCC $\left.7914^{\mathrm{T}}\right)$, Bacillus gibsonii DSM $8722^{\mathrm{T}}\left(=\right.$ MTCC $\left.7917^{\mathrm{T}}\right)$ and Bacillus alcalophilus DSM $485^{\mathrm{T}}$ (= MTCC $7913^{\mathrm{T}}$ ), from the Deutsche Sammlung von Mikroorganismen und Zellkulturen (Braunschweig, Germany).

Colony morphology was examined by studying the growth of the strain on TSA at $25^{\circ} \mathrm{C}$ for $24 \mathrm{~h}$. Cell morphology was investigated by means of light microscopy (Zeiss) at $\times 1000$ and scanning electron microscopy (Stereoscan 260; Leica). Motility was checked using the method described by Skerman (1967). The Gram reaction was determined using the HiMedia Gram-staining kit according to the manufacturer's instructions. Growth at different temperatures and $\mathrm{NaCl}$ concentrations was studied as described by Cowan \& Steel (1965). Growth at different $\mathrm{pH}$ values was tested using tryptone soya broth (HiMedia) as growth medium and the $\mathrm{pH}$ was adjusted using appropriate biological buffers (Nakajima et al., 2005). All biochemical 


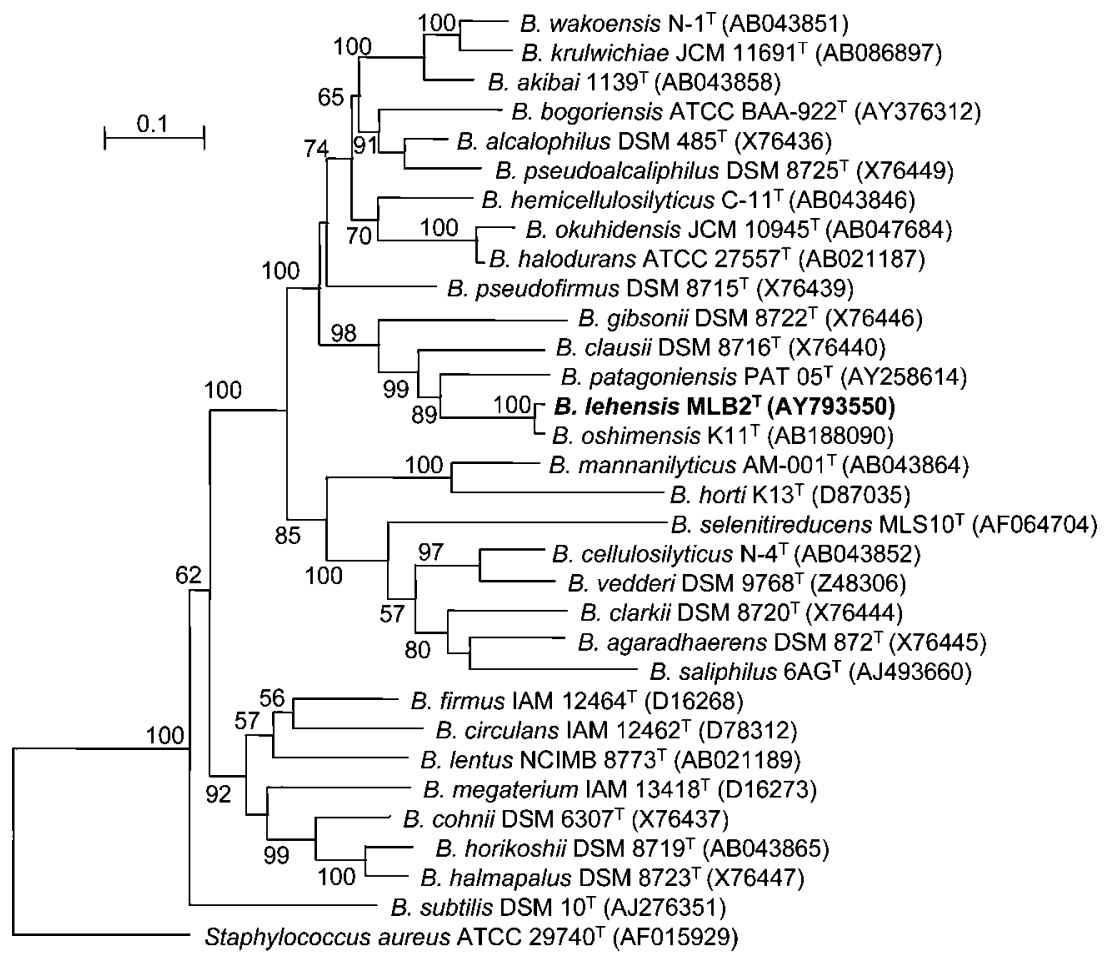

Fig. 1. Neighbour-joining phylogenetic tree indicating the position of strain $\mathrm{MLB}^{\top}$ among related species of the genus Bacillus. Bootstrap values (expressed as percentages of 1000 replications) greater than $50 \%$ are shown at the branch points. Staphylococcus aureus ATCC $29740^{\top}$ was used as an outgroup. Bar, 0.1 substitutions per site. and physiological studies were carried out at $\mathrm{pH}$ 8.0. The following characteristics were determined as described by Cowan \& Steel (1965): hydrolysis of gelatin, casein, starch, hippurate, ONPG and 4-methylumbelliferone glucuronide; Voges-Proskauer, methyl red, oxidation-fermentation tests; catalase and oxidase (oxidation of tetramethyl- $p$ phenylenediamine dihydrochloride; Sigma) activities; growth on Simmons' citrate and MacConkey agar; production of $\mathrm{H}_{2} \mathrm{~S}$ and indole; reduction of nitrate; tyrosinase activity; arginine hydrolysis; and deamination of phenylalanine. The assimilation of various substrates for growth was determined by using a Biolog GP2 MicroPlate as described by Mayilraj et al. (2006). Acid production from various carbohydrates was tested as described by Claus \& Berkeley (1986). The sensitivity of the strain to various antibiotics was tested using antibiotic-susceptibility discs (HiMedia).

Freeze-dried cells used for chemotaxonomic analyses (with the exception of the fatty acid study) were prepared after growth of the strain in tryptone soya broth for $24 \mathrm{~h}$ at $25^{\circ} \mathrm{C}$. Polar lipids were analysed as described by Suresh et al. (2004). The diagnostic amino acids and whole-cell sugars were determined using TLC, as described by Staneck \& Roberts (1974). Isoprenoid quinones were extracted (Minnikin et al., 1984) and separated by reversed-phase HPLC (Kroppenstedt, 1982). For cellular fatty acid analysis, the strains were grown on TSA and a fatty acid methyl ester analysis was then performed with the Sherlock Microbial Identification System (MIDI), as described previously (Pandey et al., 2002). The G $+\mathrm{C}$ content of genomic DNA was determined spectrophotometrically (Lambda 35; Perkin Elmer) using the thermal denaturation method (Mandel \& Marmur, 1968).
The genomic DNA was isolated using a genomic DNAisolation kit (Qiagen). PCR amplification, cloning and sequencing of the 16S rRNA gene were performed as described previously (Ghosh et al., 2006). The 16S rRNA gene sequences of closely related taxa with validly published names were retrieved from the GenBank database using BLASTN (Altschul et al., 1997) and aligned using the CLUSTAL_X program (Thompson et al., 1997); the alignment was edited manually. For the neighbour-joining analysis (Saitou \& Nei, 1987), the distances between the sequences were calculated using the method of Jukes \& Cantor (1969). A bootstrap analysis of 1000 replications was performed to assess the confidence limits of the branching (Felsenstein, 1985). DNA-DNA hybridization was performed each time with freshly isolated genomic DNA and was repeated three times using the membrane filter method (Tourova \& Antonov, 1987).

The phenotypic properties are shown in detail in Table 1 and also in the species description. Growth was observed at $\mathrm{pH}$ 7.0-11.0, but not at $\mathrm{pH} 6.0$, and the optimum $\mathrm{pH}$ for growth ( $\mathrm{pH}$ 8.0) confirmed strain $\mathrm{MLB}^{\mathrm{T}}$ to be an alkalitolerant bacterium. The cells of strain $\mathrm{MLB}^{\mathrm{T}}$ were sensitive to the following antibiotics ( $\mu \mathrm{g}$ per disc): ampicillin (10), chloramphenicol (30), ciprofloxacin (5), erythromycin (10), furazolidone (50), gentamicin (10), nalidixic acid (30), neomycin (30), oleandomycin (15), rifampicin (5), spectinomycin (100), streptomycin (10), sulphadiazine (300), sulphamethizole (300) and tetracycline (30). The cells were resistant to the following antibiotics ( $\mu \mathrm{g}$ per disc): cephaloridine (30), cloxacillin (5), colistin (10), novobiocin (30), penicillin (1.5), sulphafurazole (100), tobramycin (10) and trimethoprim (25). 
Table 1. Characteristics that differentiate strain $\mathrm{MLB}^{\top}$ from phylogenetically related type strains

Strains: 1 , MLB2 ${ }^{\mathrm{T}} ; 2$, B. oshimensis JCM $12663^{\mathrm{T}} ; 3$, B. patagoniensis DSM $16117^{\mathrm{T}} ; 4$, B. clausii DSM 8716 ${ }^{\mathrm{T}}$; 5, B. gibsonii DSM $8722^{\mathrm{T}}$; 6, B. alcalophilus DSM $485^{\mathrm{T}}$. All strains were found to produce acid from glycerol, 2-ketogluconate and D-maltose but not from inositol or Dmelezitose. All strains were positive for the assimilation of acetic acid, D-fructose, D-maltose and D-mannose, but negative for the assimilation of adenosine, D-cellobiose, 2-deoxyadenosine, D-fructose 6-phosphate, L-fucose, D-glucose 6-phosphate, D-gluconic acid, DL- $\alpha$-glycerol phosphate, $\beta$-hydroxybutyric acid, inosine, $\alpha$-ketoglutaric acid, methyl $\alpha$-D-galactoside, methyl $\alpha$-D-glucoside, stachyose and succinic acid as growth substrates (Biolog). All data were obtained from this study unless otherwise indicated. +, Positive; w, weakly positive; - , negative.

\begin{tabular}{|c|c|c|c|c|c|c|}
\hline Characteristic & 1 & 2 & 3 & 4 & 5 & 6 \\
\hline Motility & + & - & + & + & + & + \\
\hline Growth at $\mathrm{pH} 7.0$ & + & + & + & + & + & - \\
\hline Reduction of nitrate & + & - & - & + & $\mathrm{W}$ & - \\
\hline \multicolumn{7}{|l|}{ Hydrolysis of: } \\
\hline Hippurate & + & - & - & - & + & - \\
\hline 4-Methylumbelliferone glucuronide & + & + & - & - & + & - \\
\hline Tween 20 & - & + & + & - & - & - \\
\hline Tween 40 & + & + & + & - & - & + \\
\hline Tween 60 & $\mathrm{~W}$ & + & + & - & - & + \\
\hline Tween 80 & - & - & $\mathrm{W}$ & - & - & $\mathrm{W}$ \\
\hline \multicolumn{7}{|l|}{ Acid production (aerobically) from: } \\
\hline D-Arabinose & - & - & - & + & - & + \\
\hline Glycogen & + & - & $\mathrm{W}$ & - & - & + \\
\hline D-Lactose & + & - & - & - & + & + \\
\hline D-Mannose & - & + & $\mathrm{W}$ & + & + & - \\
\hline \multicolumn{7}{|l|}{ Assimilation of: ${ }^{*}$} \\
\hline$N$-Acetyl-D-glucosamine & - & - & + & + & - & $\mathrm{W}$ \\
\hline Amygdalin & - & - & + & + & + & - \\
\hline D-Arabitol & + & - & - & - & - & - \\
\hline Arbutin & + & - & + & - & + & - \\
\hline 2,3-Butanediol & - & - & + & + & - & - \\
\hline$\beta$-Cyclodextrin & + & - & - & + & $\mathrm{W}$ & - \\
\hline Dextrin & + & - & - & - & + & $\mathrm{w}$ \\
\hline D-Galactose & - & + & - & + & $\mathrm{W}$ & - \\
\hline Gentiobiose & - & - & + & - & + & - \\
\hline Glycerol & - & + & + & - & $\mathrm{W}$ & - \\
\hline 2-Ketogluconate & $\mathrm{W}$ & - & + & + & - & - \\
\hline$\alpha$-Ketovaleric acid & + & - & + & - & - & + \\
\hline Maltotriose & + & - & - & + & + & $\mathrm{w}$ \\
\hline D-Mannitol & + & - & + & $\mathrm{W}$ & + & - \\
\hline D-Melezitose & + & - & - & - & $\mathrm{W}$ & - \\
\hline Melibiose & - & - & $\mathrm{W}$ & - & + & + \\
\hline Methyl $\beta$-D-glucoside & - & + & + & + & + & $\mathrm{w}$ \\
\hline Methyl D-glucose & + & - & $\mathrm{W}$ & - & + & - \\
\hline Palatinose & + & - & - & $\mathrm{W}$ & + & - \\
\hline Propionic acid & + & - & $\mathrm{W}$ & + & - & - \\
\hline D-Psicose & + & - & - & - & + & $\mathrm{W}$ \\
\hline Pyruvic acid & + & - & - & - & + & + \\
\hline Pyruvic acid methyl ester & - & + & + & - & - & - \\
\hline D-Raffinose & - & - & + & - & + & - \\
\hline L-Rhamnose & - & - & + & - & - & + \\
\hline Salicin & - & - & + & + & + & + \\
\hline D-Sorbitol & + & - & + & + & $\mathrm{W}$ & - \\
\hline Sucrose & + & - & + & + & + & + \\
\hline D-Tagatose & - & + & - & + & - & $\mathrm{W}$ \\
\hline Thymidine & - & - & + & - & - & - \\
\hline D-Trehalose & + & - & + & + & + & - \\
\hline
\end{tabular}


Table 1. cont.

\begin{tabular}{|c|c|c|c|c|c|c|}
\hline Characteristic & 1 & 2 & 3 & 4 & 5 & 6 \\
\hline Turanose & + & - & + & + & + & + \\
\hline D-Xylose & + & + & - & - & + & - \\
\hline
\end{tabular}

${ }^{\star}$ Using Biolog GP2 microplates.

$\dagger$ Data from other studies are indicated as follows: $a$, Yumoto et al. (2005); b, Olivera et al. (2005); c, Nielsen et al. (1995). Ranges indicate data from more than one strain.

Most of the chemotaxonomic properties (presented in the species description) were typical of members of the genus Bacillus. The isoprenoid quinones present in strain MLB2 ${ }^{\mathrm{T}}$ were MK-7 and MK-6. The fatty acid methyl ester profile of the novel strain matched qualitatively those of phylogenetically related species (see Supplementary Table S1 available in IJSEM Online). The DNA G $+\mathrm{C}$ content was calculated as $41.4 \mathrm{~mol} \%$ (mean of three replications), which falls within the defined range (32-69 mol\%) accepted for Bacillus species (Fritze et al., 1990).

The complete sequence (1541 bases) of the 16S rRNA gene of strain $\mathrm{MLB}^{\mathrm{T}}$ was determined and was compared with those of closely related taxa retrieved from the GenBank database. The phylogenetic tree constructed using the neighbour-joining method suggested that this strain is a member of group 6 (Nielsen et al., 1994) of the genus Bacillus; $\mathrm{MLB}_{2}{ }^{\mathrm{T}}$ formed a clade with B. oshimensis $\mathrm{K} 11^{\mathrm{T}}$ with a bootstrap value of $100 \%$ (Fig. 1). Pairwise sequence analysis revealed that the highest sequence similarity was with B. oshimensis $\mathrm{K}_{11}{ }^{\mathrm{T}}(98.8 \%)$, followed by B. patagoniensis $\operatorname{PAT}_{05}{ }^{\mathrm{T}}(98.5 \%)$ and B. clausii DSM $8716^{\mathrm{T}}(97.3 \%)$; the remaining species with validly published names showed less than $97 \%$ similarity.

In the DNA-DNA hybridization analysis, strain MLB2 ${ }^{\mathrm{T}}$ exhibited $62 \pm 2 \%$ similarity to B. oshimensis JCM $12663^{\mathrm{T}}$, $55 \pm 3 \%$ similarity to $B$. patagoniensis DSM $16117^{\mathrm{T}}$, $51 \pm 3 \%$ similarity to B. clausii DSM $8716^{\mathrm{T}}, 34 \pm 3 \%$ similarity to $B$. gibsonii DSM $8722^{\mathrm{T}}$ and $21 \pm 2 \%$ similarity to $B$. alcalophilus DSM $485^{\mathrm{T}}$. These values for hybridization were lower than the recommended threshold value accepted for defining a novel species (Wayne et al., 1987; Stackebrandt \& Goebel, 1994), hence supporting the distinct position of strain $\mathrm{MLB}^{\mathrm{T}}$ within the genus Bacillus. On the basis of the differential phenotypic (Table 1) and genotypic properties, strain $\mathrm{MLB}^{\mathrm{T}}$ should be assigned to a novel species of the genus Bacillus, for which the name Bacillus lehensis sp. nov. is proposed.

\section{Description of Bacillus lehensis sp. nov.}

Bacillus lehensis (le.hen'sis. N.L. masc. adj. lehensis pertaining to Leh, in India, where the type strain was isolated).

Cells are aerobic, Gram-positive, motile rods $(0.5-0.8 \times 1.0-$ $3.8 \mu \mathrm{m}$ ). Oval spores develop subterminally in the cells and sporangia are not swollen. Colonies are circular, convex, smooth and pigmented creamish-yellow. Catalase and oxidase are produced. Negative for $\mathrm{H}_{2} \mathrm{~S}$, indole and urease production, in the methyl red and Voges-Proskauer tests, for ONPG hydrolysis and in the oxidation-fermentation test. No growth occurs on MacConkey agar or Simmons' citrate agar. Growth occurs at temperatures in the range $10-37^{\circ} \mathrm{C}$ (optimum temperature, $25^{\circ} \mathrm{C}$ ), $\mathrm{pH} 7.0-11.0$ (optimum, $\mathrm{pH} 8.0$ ) and at $\mathrm{NaCl}$ concentrations up to $12 \%$. Nitrate is reduced to nitrite. Assimilation of substrates for growth and production of acid from carbohydrates under aerobic conditions are shown in Table 1. Hydrolyses casein, gelatin, hippurate and starch. Negative for arginine dihydrolase, phenylalanine deaminase and tyrosinase activity; positive for 4-methylumbelliferone glucuronide activity. Cell wall contains meso-diaminopimelic acid as the diagnostic diamino acid; D-glucose, D-galactose and D-xylose are major cell-wall sugars. The predominant polar lipids are diphosphatidylglycerol, phosphatidylethanolamine and phosphatidylglycerol, along with two unknown phospholipids (PL1 and PL2). The major isoprenoid quinone is MK-7. The major cellular fatty acids are iso$\mathrm{C}_{15: 0}(57.0 \%)$, anteiso- $\mathrm{C}_{15: 0}(17.5 \%)$ and iso- $\mathrm{C}_{17: 0}$ (8.2\%). The DNA G $+\mathrm{C}$ content is $41.4 \mathrm{~mol} \%$.

The type strain, $\operatorname{MLB}^{\mathrm{T}}\left(=\right.$ MTCC $\left.7633^{\mathrm{T}}=\mathrm{JCM} 13820^{\mathrm{T}}\right)$, was isolated from soil collected from Leh, India.

\section{Acknowledgements}

We are indebted to Dr J. P. Euzéby (École Nationale Vétérinaire, France) for his suggestion regarding Latin nomenclature for the novel species. We wish to express our gratitude to Ms Gabi Pötter (DSMZ) for her excellent technical assistance. We also thank Dr K. Suresh for helpful discussions. This work was supported, in part, by CSIR and DBT, Government of India. A. G. acknowledges a research fellowship awarded by CSIR. This is IMTECH communication number 029/2006.

\section{References}

Altschul, S. F., Madden, T. L., Schaffer, A. A., Zhang, J., Zhang, Z., Miller, W. \& Lipman, D. J. (1997). Gapped BLAST and PSI-BLAST: a new generation of protein database search programs. Nucleic Acids Res 25, 3389-3402.

Claus, D. \& Berkeley, R. C. W. (1986). Genus Bacillus Cohn 1872, $174^{\mathrm{AL}}$. In Bergey's Manual of Systematic Bacteriology, vol. 2, 
pp. 1105-1139. Edited by P. H. A. Sneath, N. S. Mair, M. E. Sharpe \& J. G. Holt. Baltimore: Williams \& Wilkins.

Cowan, S. T. \& Steel, K. J. (1965). Manual for the Identification of Medical Bacteria. London: Cambridge University Press.

Felsenstein, J. (1985). Confidence limits on phylogenies: an approach using the bootstrap. Evolution 39, 783-791.

Fritze, D., Flossdorf, J. \& Claus, D. (1990). Taxonomy of alkaliphilic Bacillus strains. Int J Syst Bacteriol 40, 92-97.

Ghosh, A., Paul, D., Prakash, D., Mayilraj, S. \& Jain, R. K. (2006). Rhodococcus imtechensis sp. nov., a nitrophenol-degrading actinomycete. Int J Syst Evol Microbiol 56, 1965-1969.

Horikoshi, K. (1991). Microorganisms in Alkaline Environments. Weinheim: VCH.

Horikoshi, K. (1999). Alkaliphiles: some applications of their products for biotechnology. Microbiol Mol Biol Rev 63, 735-750.

Jukes, T. H. \& Cantor, C. R. (1969). Evolution of protein molecules. In Mammalian Protein Metabolism, vol. 3, pp. 21-132. Edited by H. N. Munro. New York: Academic Press.

Kroppenstedt, R. M. (1982). Separation of bacterial menaquinones by HPLC using reverse phase RP 18 and a silver loaded ion exchanger as stationary phases. J Liq Chromatogr 5, 2359-2387.

Mandel, M. \& Marmur, J. (1968). Use of ultraviolet absorbancetemperature profile for determining the guanine plus cytosine content of DNA. Methods Enzymol 12B, 195-206.

Mayilraj, S., Saha, P., Suresh, K. \& Saini, H. S. (2006). Ornithinimicrobium kibberense sp. nov., isolated from the Himalayas, India. Int J Syst Evol Microbiol 56, 1657-1661.

Minnikin, D. E., O'Donnell, A. G., Goodfellow, M., Alderson, G., Athalye, M., Schaal, A. \& Parlett, J. H. (1984). An integrated procedure for the extraction of bacterial isoprenoid quinones and polar lipids. J Microbiol Methods 2, 233-241.

Nakajima, K., Hirota, K., Nodasaka, Y. \& Yumoto, I. (2005). Alkalibacterium iburiense sp. nov., an obligate alkaliphile that reduces an indigo dye. Int J Syst Evol Microbiol 55, 1525-1530.

Nielsen, P., Rainey, F. A., Outtrup, H., Priest, F. G. \& Fritze, D. (1994). Comparative $16 \mathrm{~S}$ rDNA sequence analysis of some alkaliphilic bacilli and the establishment of a sixth rRNA group within the genus Bacillus. FEMS Microbiol Lett 117, 61-66.

Nielsen, P., Fritze, D. \& Priest, F. G. (1995). Phenetic diversity of alkaliphilic Bacillus strains: proposal for nine new species. Microbiology 141, 1745-1761.
Olivera, N., Sineriz, F. \& Breccia, J. D. (2005). Bacillus patagoniensis sp. nov., a novel alkalitolerant bacterium from the rhizosphere of Atriplex lampa in Patagonia, Argentina. Int J Syst Evol Microbiol 55, 443-447.

Pandey, K. K., Mayilraj, S. \& Chakraborti, T. (2002). Pseudomonas indica sp. nov., a novel butane-utilizing species. Int J Syst Evol Microbiol 52, 1559-1567.

Saitou, N. \& Nei, M. (1987). The neighbor-joining method: a new method for reconstructing phylogenetic trees. Mol Biol Evol 4, 406-425.

Skerman, V. B. D. (1967). A Guide to the Identification of the Genera of Bacteria, 2nd edn. Baltimore: Williams \& Wilkins.

Stackebrandt, E. \& Goebel, B. M. (1994). Taxonomic note: a place for DNA-DNA reassociation and $16 \mathrm{~S}$ rRNA sequence analysis in the present species definition in bacteriology. Int J Syst Bacteriol 44, 846-849.

Staneck, J. L. \& Roberts, G. D. (1974). Simplified approach to identification of aerobic actinomycetes by thin layer chromatography. Appl Microbiol 28, 226-231.

Suresh, K., Prabagaran, S. R., Sengupta, S. \& Shivaji, S. (2004). Bacillus indicus sp. nov., an arsenic-resistant bacterium isolated from an aquifer in West Bengal, India. Int J Syst Evol Microbiol 54, 1369-1375.

Thompson, J. D., Gibson, T. J., Plewniak, F., Jeanmougin, F. \& Higgins, D. G. (1997). The CLUSTAL_X windows interface: flexible strategies for multiple sequence alignment aided by quality analysis tools. Nucleic Acids Res 25, 4876-4882.

Tourova, T. P. \& Antonov, A. S. (1987). Identification of microorganisms by rapid DNA-DNA hybridization. Methods Microbiol 19, 333-355.

Ulukanli, Z. \& Diurak, M. (2002). Alkaliphilic microorganisms and habitats. Turk J Biol 26, 181-191.

Wayne, L. G., Brenner, D. J., Colwell, R. R., Grimont, P. A. D., Kandler, O., Krichevsky, M. I., Moore, L. H., Moore, W. E. C., Murray, R. G. E. \& other authors (1987). International Committee on Systematic Bacteriology. Report of the ad hoc committee on reconciliation of approaches to bacterial systematics. Int $J$ Syst Bacteriol 37, 463-464.

Yumoto, I., Yamazaki, K., Sawabe, T., Nakano, K., Kawasaki, K., Ezura, Y. \& Shinano, H. (1998). Bacillus horti sp. nov., a new Gramnegative alkaliphilic bacillus. Int J Syst Bacteriol 48, 565-571.

Yumoto, I., Hirota, K., Goto, T., Nodasaka, Y. \& Nakajima, K. (2005). Bacillus oshimensis sp. nov., a moderately halophilic, non-motile alkaliphile. Int J Syst Evol Microbiol 55, 907-911. 